\title{
PREDIKSI VITAMIN C, TOTAL ASAM TERTITRASI, DAN TOTAL PADATAN TERLARUT PADA BUAH MANGGA MENGGUNAKAN NEAR-INFRARED REFLECTANCE SPECTROSCOPY
}

\section{Prediction of Vitamin C, Titratable Acidity, and Soluble Solids Content of Mango Fruits Using Near-Infrared Reflectance Spectroscopy}

\author{
Kusumiyati $^{1 *}$, Agus Arip Munawar ${ }^{2}$, Diding Suhandy ${ }^{3}$ \\ ${ }^{1}$ Departemen Budidaya Pertanian - Fakultas Pertanian - Universitas Padjadjaran \\ Jl. Raya Bandung Sumedang KM.21 - Hegarmanah - Jatinangor - Sumedang - Jawa Barat 45363 \\ ${ }^{2} J u r u s a n$ Teknik Pertanian - Fakultas Pertanian - Universitas Syiah Kuala \\ Jl. Teuku Nyak Arief Darussalam - Banda Aceh - Aceh 23111 \\ ${ }^{3}$ Jurusan Teknik Pertanian - Fakultas Pertanian - Universitas Lampung \\ Jl. Prof. Dr. Ir. Sumantri Brojonegoro No. 1 - Gedong Meneng - Rajabasa - Bandar Lampung - Lampung 35141 \\ *Penulis Korespondensi, email: kusumiyati@unpad.ac.id
}

Disubmit: 6 November 2019 Direvisi: 17 September 2020 Diterima: 12 Oktober 2020

\begin{abstract}
ABSTRAK
Buah mangga memiliki kandungan nutrisi yang bermanfaat bagi kesehatan. Komoditas ini tersedia di pasar dalam berbagai jenis kulitvar, diantaranya cengkir, kweni, kent, dan palmer. Tujuan penelitian ini adalah memprediksi kualitas internal buah mangga yaitu vitamin $C$, total asam tertitrasi, dan total padatan terlarut (TPT) menggunakan near-infrared reflectance spectroscopy (NIRS). Spektra diffuse reflectance yang diperoleh dari hasil akuisisi spektra dikoreksi dengan pra-pengolahan spektra metode orthogonal signal correction (OSC), dan turunan pertama savitzkygolay (dg1). Hasil penelitian menjelaskan bahwa vitamin C, total asam tertitrasi, dan TPT dapat diprediksi dengan baik menggunakan NIRS. Pra-pengolahan spektra memberikan pengaruh terhadap akurasi pendugaan kualitas internal buah mangga. Spektra dg1 memperoleh nilai $\mathrm{R}^{2}$ kalibrasi tertinggi pada ketiga parameter kualitas yaitu 0,98 (vitamin C), 0,87 (total asam tertitrasi), dan 0,96 (TPT). Namun, pada pendugaan vitamin C dan total padatan terlarut, spektra dg1 menampilkan nilai konsisten yang rendah yaitu sebesar 56\% dan 63\%. Pra-pengolahan spektra OSC mampu mereduksi jumlah faktor pada spektra original. Model kalibrasi terbaik pendugaan vitamin $C$ dan total padatan terlarut diperoleh oleh spektra original, sedangkan pendugaan total asam tertitrasi ditunjukkan oleh spektra dg1
\end{abstract}

Kata kunci : Analisis Multivariat; Kalibrasi; Kemometrika; Nondestruktif; Validasi

\section{ABSTRACT}

Mango fruit contains a lot of beneficial nutrition for health. This commodity is available at the market in various cultivars, including cengkir, kweni, kent, and palmer. The purpose of the research was to predict the internal quality of mango such as vitamin $C$, titratable acidity, and soluble solid content using near-infrared reflectance spectroscopy (NIRS). Diffuse reflectance spectra acquired from spectra acquisition were corrected using spectra pre-processing methods of orthogonal signal correction (OSC) and first derivative savitzky-golay (do1). The results explained that vitamin $C$, titratable acidity, and SSC were able to be properly predicted using NIRS. Spectra pre-processing gave effect to the accuracy of internal quality prediction of mango. Dg1 spectra obtained the highest calibration $R^{2}$ in the three quality parameters of 0.98 (vitamin C), 0.87 (titratable acidity), and 0.96 (SSC). However, in vitamin $c$ and SSC prediction, dg1 spectra yielded low consistent values of $56 \%$ and $63 \%$. Besides, OSC spectra preprocessing was able to reduce the number of factors in the original spectra. The best calibration model for predicting vitamin $c$ and total dissolved solids was achieved by the original spectra, while the prediction of titratable acidity was shown by dg1 spectra

Keywords : Calibration; Chemometrics; Multivariate Analysis; Nondestructive; Validation 


\section{PENDAHULUAN}

Kualitas merupakan faktor yang penting untuk diperhatikan dalam industri hortikultura. Selera konsumen menjadi penentu standardisasi kualitas suatu produk. Buah menjadi salah satu bagian dari produk hortikultura yang kriteria kualitasnya didasarkan atas permintaan pasar. Kualitas eksternal dan internal buah dapat diukur secara kuantitatif. Pengukuran kualitas eksternal buah seperti ukuran dan bobot buah lebih mudah dilakukan dengan bantuan jangka sorong dan timbangan. Namun, pengukuran kualitas internal buah seperti total padatan terlarut (TPT), vitamin C, asam titrasi, antioksidan, dan sebagainya membutuhkan keahlian khusus, peralatan yang canggih dan biaya yang besar karena pengujian dilakukan di laboratorium.

Analisis destruktif dan non-destruktif telah banyak dikenal sebagai cara pengujian kualitas pada buah. Analisis destruktif merupakan pengujian yang menyebabkan kerusakan pada buah, sedangkan analisis non-destruktif merupakan pengujian tanpa merusak buah sehingga tidak menimbulkan kerugian karena buah masih utuh dan dapat dipasarkan. Teknik near-infrared reflectance spectroscopy (NIRS) adalah bagian dari analisis nondestruktif yang telah banyak digunakan untuk mengukur kualitas pada berbagai jenis buah. NIRS dapat dimanfaatkan untuk mengetahui kandungan nutrisi buah, diantaranya buah oyong (Kusumiyati et al., 2017), sawo (Kusumiyati et al., 2018), apel (Angra et al., 2009), kiwi (Lue et al., 2010), mangga (Munawar dan Budiastra, 2009), dan stroberi (Shao dan He, 2008). Kelebihan NIRS dibandingkan analisis nondestruktif lainnya adalah NIRS lebih fleksibel, cepat, simultan dan dapat memprediksi parameter kualitas yang konsentrasinya rendah (Cope dan Delpy, 1988). NIRS telah banyak diaplikasikan oleh peneliti dan pelaku dunia industri. Teknik ini memanfaatkan interaksi antara cahaya yang bersumber dari spektrometer dan bahan organik pada sampel yang dianalisis. Selanjutnya, analisis kemometrik digunakan untuk mengekstrak informasi pada spektra NIRS melalui persamaan regresi linear. Selanjutnya, dari persamaan regresi linear, akan diperoleh model kalibrasi parameter kualitas yang diinginkan. Metode yang paling banyak digunakan untuk mengembangkan model kalibrasi yaitu partial least square regression (PLSR). Metode ini dapat memperkirakan berbagai variabel bebas dan variabel terikat dalam jumlah yang sangat banyak. Pada metode PLSR, variabel Y (variabel respon) dan variabel X (variabel prediktor) diolah secara bersamaan dan digunakan dalam membentuk suatu prediksi serangkaian bahan organik (Yan-De et al., 2007). Keakuratan model kalibrasi dapat diuji dengan validasi. Uji validasi dapat dilakukan dengan menggunakan sampel buah yang sama (validasi silang) atau sampel berbeda (independen).

Buah mangga merupakan salah satu buah yang memiliki karakteristik yang khas dan kandungan nutrisi yang tinggi. Buah ini memiliki beragam jenis kultivar seperti cengkir, kweni, kent, dan palmer. Secara umum, buah mangga yang telah matang memiliki rasa manis namun masih terdapat rasa asam dan daging buahnya berwarna kekuningan. Ara et al. (2014) melaporkan bahwa buah mangga mempunyai kandungan vitamin $C$ terbesar $(26,53-46,53 \mathrm{mg} / 100 \mathrm{~g})$, total gula $(4,27-5,48 \%$ Brix), dan asam tertitrasi $(0,75 \%)$.

Pendugaan nilai TPT, total asam tertitrasi, dan vitamin $C$ menggunakan teknik NIRS telah banyak diterapkan pada berbagai jenis buah-buahan seperti buah nanas (Amuah et al., 2019), sawo (Kusumiyati et al., 2018) dan jeruk (Suhandy, 2010). Schmilovitch et al. (2000) melaporkan penggunaan NIRS untuk memprediksi kandungan internal buah mangga yang meliputi TPT, total asam, dan kekerasan diikuti dengan metode PLSR. Nilai TPT dipengaruhi oleh banyaknya kandungan padatan terlarut seperti protein, gula reduksi, pektin, gula non-reduksi dan asam-asam organik. Hasil analisis keasaman pada buah tomat menghasilkan model kalibrasi dengan nilai koefisien determinasi $\left(R^{2}\right)$ sebesar 0,92 (Petcharaporn dan Kumchoo, 2014), sedangkan pada buah apricot berhasil diketahui nilai $\mathrm{R}^{2}$ kalibrasi yaitu 0,95 (Oliveira et al., 2014). Vitamin C atau asam askorbat mengandung karbon (C), hidrogen $(\mathrm{H})$ dan oksigen $(\mathrm{O})$. Spektrum NIRS menggambarkan berbagai ikatan kimia yaitu $\mathrm{O}-\mathrm{H}$, $\mathrm{N}-\mathrm{H}$ dan $\mathrm{C}-\mathrm{H}$, sehingga NIRS sangat berguna untuk digunakan dalam memprediksi kandungan vitamin C (Liu et al., 2006). Pada pendugaan nilai vitamin $C$ telah diujikan pada buah acerola (Moraes et al., 2019), apel (Pissard et al., 2012), tomat (Azadshahraki et al., 2008) dan paprika (Ignat et al., 2012).

Spektra yang dihasilkan pada pengambilan data spektra sampel seringkali 
masih mengandung noise. Hal tersebut dapat menurunkan tingkat keakuratan model kalibrasi yang akan dikembangkan. Noise dapat direduksi dengan perlakuan pra-pengolahan spektra. Jenis pra-pengolahan spektra yang banyak digunakan adalah Orthogonal Signal Correction (OSC) dan first derivative SavitzkyGolay (dg1). Pemilihan metode pra-pengolahan spektra merupakan tahap yang krusial. Mouazen et al. (2005) menyebutkan bahwa pra-pengolahan spektra yang digunakan untuk membangun model kalibrasi NIRS dipengaruhi oleh kandungan kimia dan jenis bahan dari produk yang dianalisis. Prapengolahan spektra metode OSC dan dg1 sudah pernah dipakai untuk memperbaiki data pada buah mangga gedong gincu (Sari et al., 2016), kopi (Esteban-Díez et al., 2004) dan mangga arumanis (Agustina et al., 2015). Penelitian ini bertujuan untuk memprediksi kandungan vitamin $\mathrm{C}$, total asam tertitrasi, dan total padatan terlarut pada buah mangga menggunakan NIRS.

\section{METODE}

\section{Persiapan Sampel}

Total sampel yang digunakan pada penelitian ini sebanyak 70 sampel buah utuh yang terdiri dari kultivar Cengkir, Kent, Kweni, dan Palmer yang diperoleh dari pasar buah. Penyimpanan sampel dilakukan selama 10, 12, dan 14 hari. Buah mangga merupakan tipe klimakterik, oleh karena itu terjadi perubahan pada parameter kualitasnya selama penyimpanan (Kusumiyati et al., 2018). Sebelum akuisisi data spektra, masingmasing sampel diberi nomor sehingga tidak tertukar saat tahap analisis.

\section{Akuisisi Data Spektra}

Pengamiblan data spektra dilakukan pada sampel buah utuh. Instrumen NIRS, thermos Nicolet Antaris TM 2, model MDS (Method Development Sampling), atenuasi optik $4 x$, rentang panjang gelombang 1000-2500 nm, sensor InGaS dan dengan Beam Splitter digunakan untuk memperoleh data spektra buah mangga. Masing-masing sampel buah diradiasi sebanyak 3 kali yang meliputi bagian pangkal, tengah, dan ujung bawah buah. Selanjutnya diambil nilai ratarata dari ketiga pengukuran tersebut, sehingga diperoleh 1 spektrum per sampel. Data spek- tra yang diperoleh berupa diffuse reflectance, yaitu cahaya yang diserap sementara oleh sampel kemudian dipantulkan kembali dan diterima oleh detektor pada spektrometer.

\section{Pengukuran Vitamin C, Total Asam Tertitrasi, dan Total Padatan Terlarut}

Ketika pengambilan data spektra selesai, selanjutnya buah diiris pada 3 bagian sesuai dengan titik pengambilan data spektra. Pengukuran vitamin C dilakukan dengan metode titrasi menggunakan reagen 2,6-diklorofenolindofenol (Arya et al., 2000). 5 g sampel dicampur dengan $20 \mathrm{ml}$ dari 5\% asam metafosfat. Pencampuran ini bertujuan agar kandungan vitamin $C$ tidak cepat teroksidasi karena terpapar oleh suhu, cahaya, dan lain-lain. Selanjutnya, larutan tersebut dihomogenisasi menggunakan alat homogenizer, untuk kemudian dilakukan penambahan air aquades pada larutan hingga volume $50 \mathrm{ml}$ tercapai. Sebanyak $10 \mathrm{ml}$ dari larutan di saring menggunakan kertas saring dan dipindahkan ke dalam beaker glass. Tahap titrasi dilakukan menggunakan 0,064 M 2,6-diklorofenolindofenol hingga muncul warna merah muda. Volume akhir titrasi dicatat dan dilakukan penetapan blanko. Kandungan vitamin $C$ dalam sampel dinyatakan dalam mg.100g $\mathrm{g}^{-1}$. Pengukuran total padatan terlarut buah diperoleh dari jus buah yang kemudian dilakukan pemisahan antara campuran padat dan cair yang tidak saling larut, sehingga diperoleh supernatan dan endapan. Supernatan diteteskan pada detektor refraktometer, selanjutnya akan didapatkan nilai ${ }^{\circ}$ Brix sampel tersebut. Pengukuran total asam tertitrasi dijalankan menggunakan titrator otomatis dengan $0,1 \mathrm{~N} \mathrm{NaOH}$ hingga ke titik akhir $\mathrm{pH} 8,1$. Nilai total asam tertitrasi diekspresikan dalam mg.100g-1 (Flores et al., 2009).

\section{Pra-Pengolahan Spektra}

Spektra yang diperoleh dari hasil akuisisi data spektra memerlukan perbaikan untuk meningkatkan nilai akurasi pendugaan. Hal ini dikarenakan spektra asli umumnya mengandung informasi latar belakang, efek hamburan, noise, dan lain-lain. Pra-pengolahan spektra yang diterapkan pada penelitian ini adalah OSC dan dg1. Metode OSC menyeleksi spektra yang tidak relevan dengan respon, sehingga saat analisis regresi, yang tersisa hanya spektra yang relevan dengan respon. Metode dg1 dapat memunculkan 
informasi yang tersembunyi pada spektra, metode ini biasanya digunakan untuk memprediksi kandungan yang jumlahnya sedikit.

\section{Pemodelan Kalibrasi, Validasi, dan Evaluasi Model}

Pengembangan model kalibrasi bertujuan untuk memperoleh model pendugaan kandungan kimia buah mangga. Pada penelitian ini, metode PLSR digunakan untuk pengembangan model kalibrasi. Validasi merupakan tahapan untuk pengecekan model kalibrasi yang telah diperoleh. Metode $K$-fold cross validation diterapkan untuk tahapan validasi model (Cozzolino et al., 2011; Munawar et al., 2016). Validasi dilakukan menggunakan data kalibrasi dikarenakan keterbatasan data yang tersedia. Hasil dari pemodelan kalibrasi dan validasi dievaluasi dengan nilai $\mathrm{R}^{2}$, root mean squares error of calibration (RM$\mathrm{SEC})$, root mean squares error of cross validation (RMSECV), ratio performance to deviation (RPD), dan konsistensi. Software pendukung yang digunakan pada penelitian ini adalah Microsoft Excel 2019 dan The Unscrambler 10.4 untuk pra-pengolahan data spektra, kalibrasi, dan validasi.

\section{HASIL DAN PEMBAHASAN}

\section{Analisis Spektra Diffuse Reflectance Buah Mangga}

Pada dasarnya buah-buahan mengandung 80-90\% berbagai molekul kompleks seperti asam organik, karbohidrat, protein, dan unsur lainnya (Gómez et al., 2006). Prinsip NIRS yaitu dengan memanfaatkan interaksi antara gelombang elektromagnetik yang dipancarkan oleh spektrometer dengan bahan organik. Maka dari itu spektra NIR pada buah-buahan menunjukkan hasil yang luas dan kompleks akibat dari interaksi ikatan hidrogen dengan berbagai molekul yang berbeda (Golic et al., 2003). Hasil pengukuran spektra NIRS menyediakan informasi mengenai parameter kualitas sampel yang diradiasi dengan melibatkan respon ikatan molekul seperti C-H, O-H, N-H, dan C-O. Gambar 1 menampilkan spektra diffuse reflectance pada 4 kultivar mangga yaitu cengkir, kent, kweni, dan palmer. Kandungan kimia pada sampel yang diradiasi menyebabkan adanya puncak dan lembah pada spektra yang diperoleh (Blanco dan Villarroya, 2002). Puncak pada spektra diffuse re- flectance buah mangga muncul pada panjang gelombang $1140-1200 \mathrm{~nm}, 1400-1500 \mathrm{~nm}$, dan 1900-2050 nm, sedangkan lembah terlihat pada $1260-1280 \mathrm{~nm}, 1640-1820 \mathrm{~nm}$, dan $2150-$ $2300 \mathrm{~nm}$. Puncak pada panjang gelombang 1445 dan $1920 \mathrm{~nm}$ terdeteksi sebagai ikatan $\mathrm{O}-\mathrm{H}$ yang berkaitan dengan kandungan air (Büning-Pfaue, 2003). Lanza dan Li (1984) melaporkan bahwa panjang gelombang 1460 , 1800, dan $2270 \mathrm{~nm}$ berasosiasi dengan kandungan glukosa, sukrosa, dan fruktosa. Pada penelitian lain dipaparkan bahwa panjang gelombang 1400-1510 nm berkorelasi dengan kandungan vitamin C (Liu et al., 2006). Panjang gelombang 1170, 1450, dan $2250 \mathrm{~nm}$ mengindikasikan kandungan asam seperti asam askorbat, sitrat, dan malat.

\section{Pengaruh Pra-Pengolahan Spektra NIRS}

Pra-pengolahan spektra NIRS merupakan tahap yang penting dilakukan sebelum mengembangkan model kalibrasi. Spektra yang diperoleh dari spektrometer mengandung informasi tentang sampel, selain itu juga memuat noise dan informasi latar belakang (Cen dan He, 2007). Chen et al. (2013) menyatakan bahwa noise yang muncul pada spektra diakibatkan karena perbedaan ukuran partikel antara sampel yang dianalisis dan gelombang elektromagnetik yang dipancarkan spektrometer. Pada umumnya, pra-pengolahan spektra pada spektra yang dilakukan sebelum tahap kalibrasi akan meningkatkan akurasi model kalibrasi. Pemilihan metode pra-pengolahan spektra yang digunakan bergantung pada jenis kandungan kimia pada sampel yang akan diprediksi (Mouazen et al., 2005).

Gambar 2 menunjukkan spektra original, dg1, dan OSC (vitamin C). Metode derivatif turunan pertama savitzky-golay (dg1) terdiri dari 2 tahap yaitu transformasi dan penghalusan (smoothing). Spektra original (RAW) ditransformasi menggunakan metode derivatif turunan pertama, setelah itu dilakukan penghalusan menggunakan metode savitzky-golay sebanyak 9 titik penghalusan yang terdiri dari masing-masing 4 titik bagian kiri dan kanan, serta 1 titik pada bagian tengah spektra. Metode ini bertujuan untuk memperjelas puncak dan lembah pada spektra. Sebagai tambahan, metode dg1 mengurangi efek baseline, informasi latar belakang, dan mengurai spektra yang tumpang tindih. Prinsip kerja metode OSC yaitu mereduksi variabel prediktor atau data spektra 
Jurnal Teknologi Pertanian Vol. 21 No. 3 [Desember 2020] 145-154 Prediksi Vitamin C, Total Asam Tertitrasi, dan Total Padatan Terlarut Pada Buah Mangga [Kusumiyati dkk]

Tabel 1. Hasil analisis kalibrasi dan validasi pendugaan kandungan kimia buah mangga

\begin{tabular}{lcccccccc}
\hline \multirow{2}{*}{$\begin{array}{c}\text { Parameter } \\
\text { Kualitas }\end{array}$} & $\begin{array}{c}\text { Pra- } \\
\text { pengolahan } \\
\text { spektra }\end{array}$ & Faktor & $\begin{array}{c}\mathrm{R}^{2} \\
\text { Kalibrasi }\end{array}$ & RMSEC & $\begin{array}{c}\mathrm{R}^{2} \\
\text { Validasi } \\
\text { Silang }\end{array}$ & RMSECV & RPD & $\begin{array}{c}\text { Kon- } \\
\text { sistensi } \\
(\%)\end{array}$ \\
\hline \multirow{3}{*}{ Vitamin C } & Original & 8 & 0,93 & 3,31 & 0,92 & 3,89 & 3,47 & 85 \\
\cline { 2 - 9 } & OSC & 3 & 0,91 & 4,05 & 0,90 & 4,50 & 3,08 & 89 \\
\cline { 2 - 9 } & $\mathrm{dg} 1$ & 10 & 0,98 & 2,03 & 0,93 & 3,60 & 4,03 & 56 \\
\hline \multirow{2}{*}{$\begin{array}{l}\text { Total } \\
\text { Asam } \\
\text { Tertitrasi }\end{array}$} & Original & 3 & 0,81 & 46,91 & 0,79 & 49,91 & 2,18 & 93 \\
\cline { 2 - 9 } & OSC & 1 & 0,84 & 56,15 & 0,85 & 57,84 & 2,48 & 97 \\
\hline $\begin{array}{l}\text { Total } \\
\text { Padatan } \\
\text { Terlarut }\end{array}$ & Original & 1 & 0,87 & 44,56 & 0,85 & 49,17 & 2,61 & 90 \\
\cline { 2 - 9 } & OSC & 1 & 0,89 & 1,03 & 0,89 & 1,05 & 3,09 & 97 \\
\hline
\end{tabular}

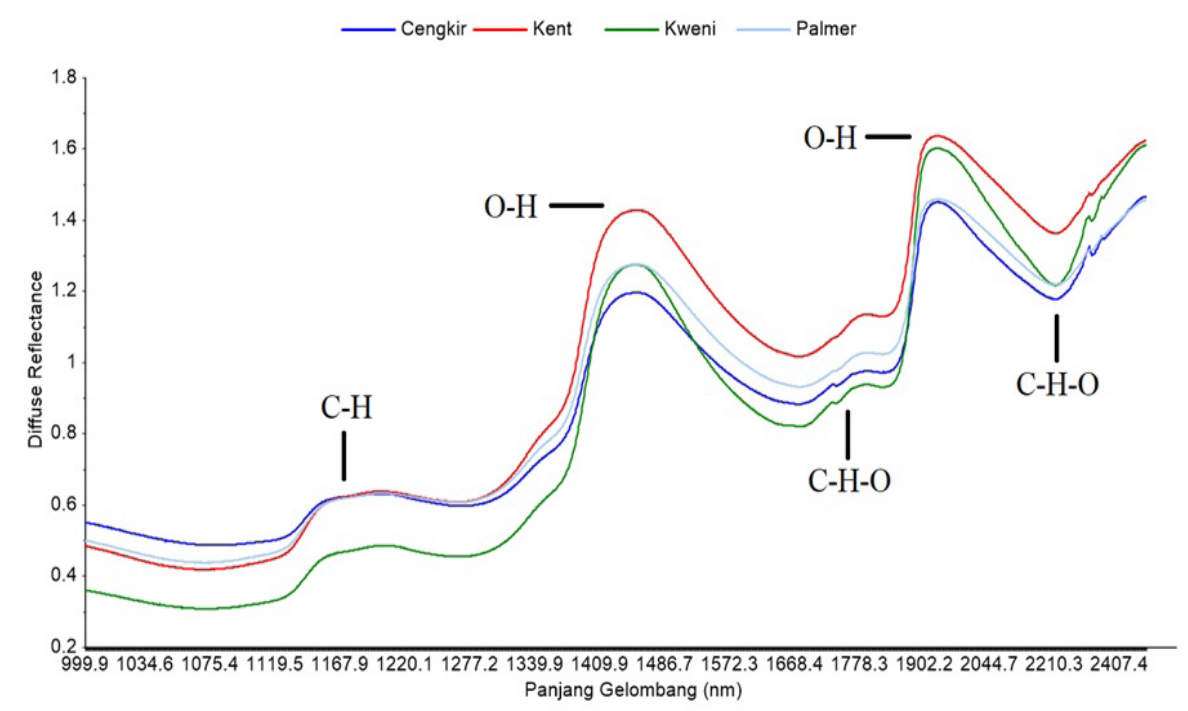

Gambar 1. Spektra diffuse reflectance buah mangga pada masing-masing kultivar

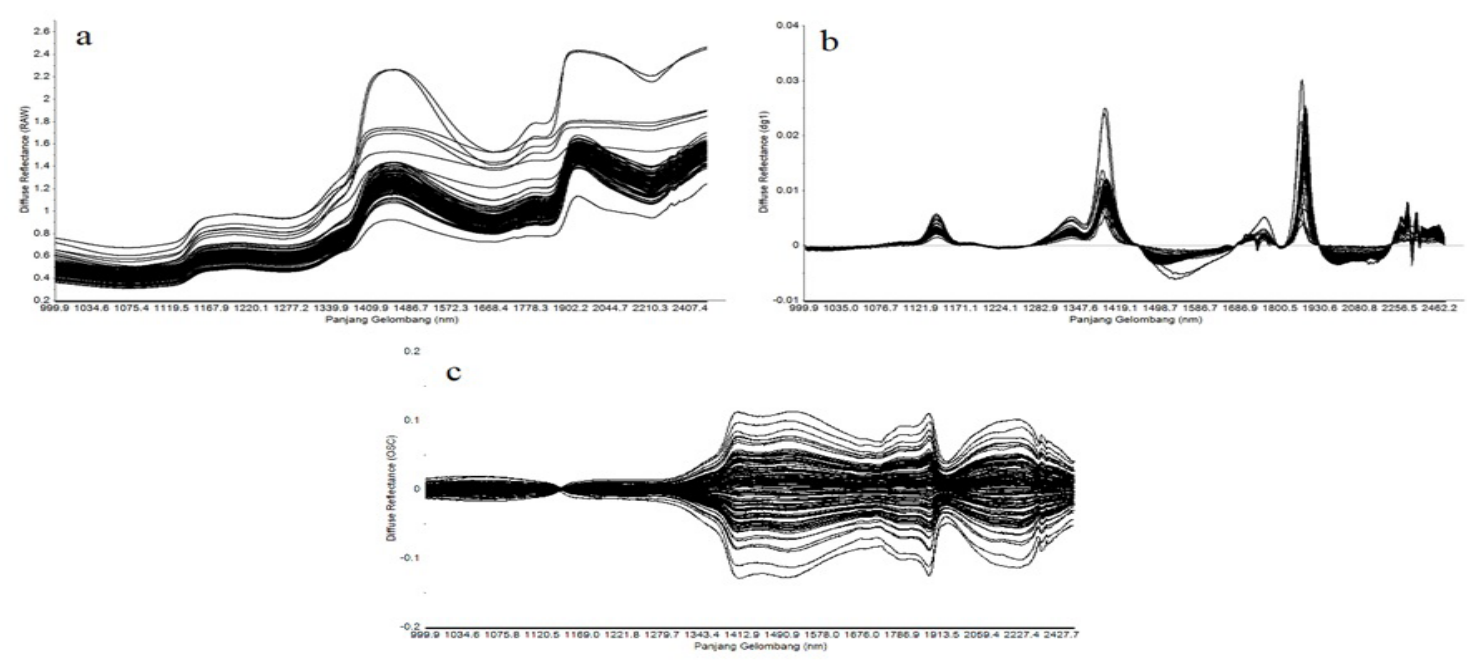

Gambar 2. a) spektra original, b) spektra dg1, c) spektra OSC (vitamin C) 
yang tidak berkorelasi dengan variabel respon atau data referensi (Laref et al., 2017). Menurut Hai-bin et al. (2005) metode OSC mereduksi spektra yang ortogonal terhadap data respon, selanjutnya spektra tersebut diuraikan kedalam bentuk skor menggunakan Principal Component Analysis (PCA).

\section{Kalibrasi dan Validasi Kandungan Kimia Buah Mangga}

Tabel 1 menunjukkan hasil kalibrasi dan validasi pada ketiga parameter kualitas buah mangga. Hasil kalibrasi dan validasi vitamin $\mathrm{C}$ memperlihatkan nilai yang berbeda pada masing-masing pra-pengolahan spektra. Spektra dg1 memperoleh nilai $\mathrm{R}^{2}$ kalibrasi tertinggi yaitu 0,98 , diikuti dengan spektra original sebesar 0,93, dan spektra OSC sebesar 0,91. Selain itu, model pendugaan yang baik memiliki nilai RMSEC dan RMSECV yang tidak berbeda jauh. Oleh karena itu dihitung juga rasio antara RMSEC dan RMSECV (konsistensi). Spektra dg1 menampilkan nilai $\mathrm{R}^{2}$ kalibrasi dan RPD tertinggi sebesar 0,98 dan 4,03, namun nilai konsistensi yang diperoleh hanya $56 \%$. William dan Norris (1990) menyatakan bahwa nilai konsistensi yang baik berkisar antara $80-110 \%$. Hal ini berarti rasio di antara RMSEC dan RMSECV pada spektra dg1 cukup tinggi. Oleh karena itu, model kalibrasi dari spektra original lebih dapat diandalkan untuk pendugaan kandungan vitamin $\mathrm{C}$ dengan nilai $\mathrm{R}^{2}$ kalibrasi yaitu 0,93 dan nilai konsistensi sebesar $85 \%$.

Model pendugaan terbaik total asam tertitrasi buah mangga ditampilkan oleh pra-pengolahan spektra metode dg1 dengan nilai $\mathrm{R}^{2}$ kalibrasi sebesar 0,87 , disamping itu, nilai RPD yang diperoleh spektra dg1 merupakan yang tertinggi yaitu 2,48. Pada penelitian lain, Sari et al. (2016) melaporkan bahwa pendugaan kandungan total asam buah mangga gedong gincu memperoleh nilai akurasi lebih tinggi daripada spektra original dengan $\mathrm{R}^{2}$ sebesar 0,74 dan nilai RPD yang didapatkan ialah 1,33. Penggunaan pra-pengolahan spektra metode dg1 mampu memperjelas dan memunculkan informasi tersembunyi pada spektra NIRS, sehingga dapat meningkatkan nilai akurasi pendugaan total asam tertitrasi pada buah mangga.

Pra-pengolahan spektra dengan metode dg1 memperoleh nilai $\mathrm{R}^{2}$ kalibrasi tertinggi pada pendugaan kandungan total padatan terlarut sebesar 0,96. Namun, nilai konsistensi yang didapatkan pada spektra dg1 ini hanya $63 \%$. Selain itu, jumlah faktor yang diperoleh jauh lebih tinggi dibandingkan dua spektra lainnya yaitu 9. Nilai faktor yang terlalu tinggi dapat diartikan adanya gangguan pada spektra yang dianalisis. Jankovska dan Sustova (2003) mengungkapkan bahwa nilai faktor yang tinggi akan mengurangi kemampuan model untuk memprediksi. Model pendugaan total padatan terlarut terbaik ditunjukkan oleh spektra original dengan nilai $\mathrm{R}^{2}$ kalibrasi sebesar 0,89 dan nilai konsistensi yaitu 97\%. Nilai RPD yang diperoleh pada spektra original yaitu 3,09. Nicolai et al. (2007) menyatakan bahwa nilai RPD>3 menandakan bahwa model pendugaan yang dikembangkan memiliki akurasi yang tinggi.
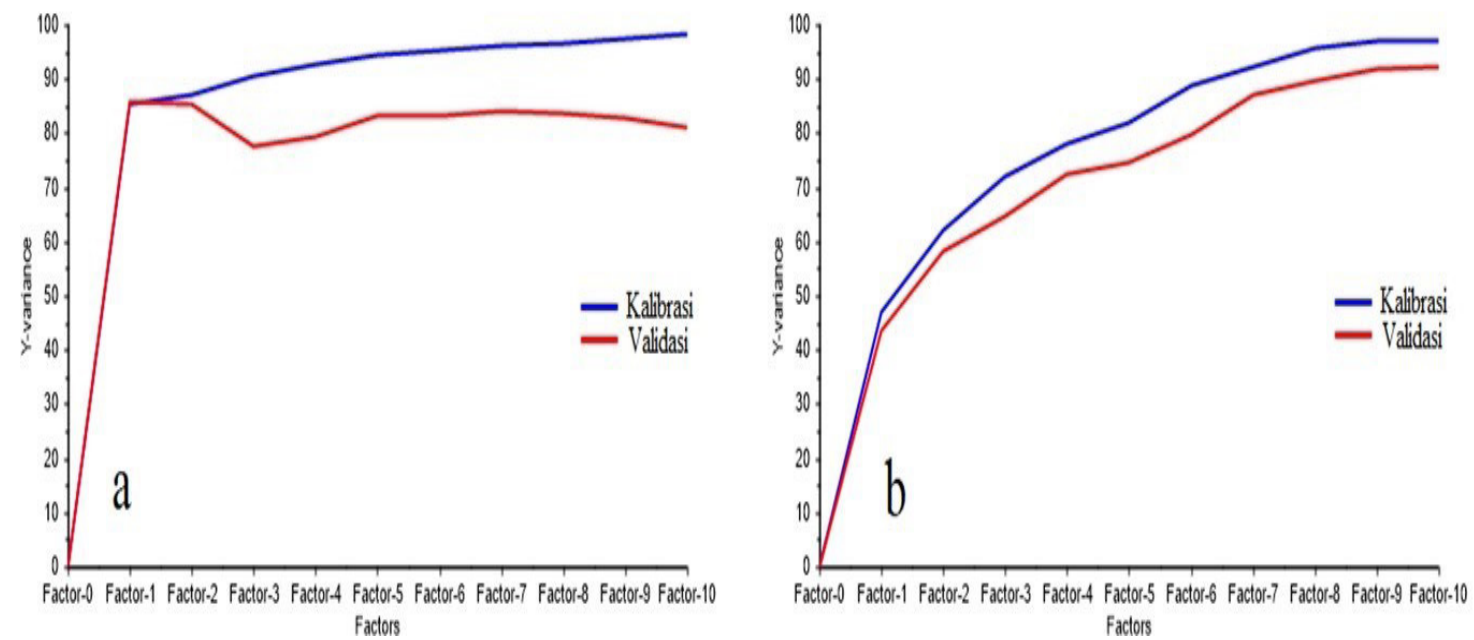

Gambar 3. Explained variance pada spektra OSC (a) dan dg1 (b) parameter total padatan terlarut 
Pada ketiga parameter kualitas buah yang diamati, spektra OSC menampilkan jumlah faktor yang terendah dibandingkan spektra lainnya. Pra-pengolahan spektra metode OSC mampu mereduksi keragaman spektra NIRS sehingga jumlah faktor yang diperoleh pada analisis regresi lebih rendah. Penentuan jumlah faktor yang optimum didasarkan pada perhitungan Predictive Residual Error Sum of Squares (PRESS). Jumlah faktor yang optimum ditentukan pada nilai PRESS yang terendah. Visualisasi penentuan faktor yang optimum dapat dilihat pada plot explained variance set kalibrasi dan validasi (Gambar 3). Faktor yang optimum dilihat dari variance tertinggi dan jarak terdekat pada garis kalibrasi dan validasi. Explained variance merupakan persentase variasi pada variabel respon yang dapat dijelaskan oleh variabel prediktor. Jumlah faktor optimum pada spektra OSC pendugaan total padatan terlarut yaitu 1 dengan nilai explained variance kalibrasi (85\%) dan validasi (85\%) (Gambar 3a.), sedangkan pada spektra dg1 jumlah faktor optimumnya yaitu 9 dengan nilai $e x$ plained variance kalibrasi (96\%) dan validasi $(91 \%)$ seperti yang ditunjukkan pada Gambar $3 b$.

\section{SIMPULAN}

Kandungan vitamin $C$, total padatan tertitrasi, dan total padatan terlarut dapat diprediksi menggunakan NIRS. Pra-pengolahan spektra NIRS memberikan pengaruh terhadap nilai akurasi pendugaan kualitas internal buah mangga. Spektra OSC menampilkan nilai faktor yang paling rendah pada ketiga parameter kualitas buah mangga. Model terbaik pendugaan vitamin $C$ dan total padatan terlarut diperoleh oleh spektra original dengan nilai $\mathrm{R}^{2}$ masing-masing sebesar 0.93 dan 0.89 , sedangkan pada pendugaan total asam tertitrasi ditunjukkan oleh spektra dg1 dengan nilai $\mathrm{R}^{2}$ sebesar 0.91 .

\section{UCAPAN TERIMA KASIH}

Penulis mengucapkan terima kasih kepada Kemenristek Dikti Republik Indonesia atas dana penelitian melalui program PDUPT 2019.

\section{KONFLIK KEPENTINGAN}

Penulis menyatakan tidak ada konflik kepentingan dalam penulisan naskah karya ilmiah ini.

\section{DAFTAR PUSTAKA}

Agustina, -S., Purwanto, Y, -A., Budiastra, I, -W., 2015. Prediksi kandungan kimia mangga arumanis selama penyimpanan dengan spektroskopi NIR. Jurnal Keteknikan Pertanian. 3(1), 57-63. https://journal.ipb.ac.id/index.php/ jtep/article/view/9679

Amuah, C, L, -Y., Teye, -E., Lamptey, F, -P., Nyandey, -K., Opoku-Ansah, -J., Adueming, P, -O., 2019. Feasibility study of the use of handheld NIR spectrometer for simultaneous authentication and quantification of quality parameters in intact pineapple fruits. Journal of Spectroscopy. 2019, 1-9. https://doi.org/10.1155/2019/5975461

Angra, S, -K., Dimri, A, -K., Kapur, -P., 2009. Nondestructive brix evaluation of apples of different origin using near infrared (NIR) filter based reflectance spectroscopy. Instrumentation Science and Technology. 37(2), 241-253. https:// doi.org/10.1080/10739140902735704

Ara, -R., Motalab, -M., Uddin, M, -N., Fakhruddin, A, N, -M., Saha, B, -K., 2014. Nutritional evaluation of different mango varieties available in Bangladesh. International Food Research Journal. 21(6), 2169-2174. http:// www.ifrj.upm.edu.my/21\%20(06)\%20 2014/16\% 20IFRJ\% 2021\% 20(06)\% 20 2014\%20Saha\%20022.pdf

Arya, S, -P., Mahajan, -M., Jain, -P., 2000. Nonspectrophotometric methods for the determination of vitamin C. Analytica Cimica Acta. 417(1), 1-14. https:/ / doi. org/10.1016/S0003-2670(00)00909-0

Azadshahraki, -F., Jamshidi, -B., Sharabiani, V, -R., 2008. Non-destructive Determination of vitamin $\mathrm{C}$ and lycopene contents of intact $\mathrm{cv}$. newton tomatoes using NIR spectroscopy. Yuzuncu Yil University Journal of Agricultural Sciences. 28(4), 389-397. https://doi. org/10.291337yyutbd.423458 
Blanco, -M., Villarroya, -I., 2002. NIR spectroscopy: A rapid-response analytical tool. TrAC - Trends in Analytical Chemistry. 21(4), 240-250. https:/ / doi. org/10.1016/S0165-9936(02)00404-1

Büning-Pfaue, -H., 2003. Analysis of water in food by near infrared spectroscopy. Food Chemistry. 82(1), 107-115. https://doi.org/10.1016/ S0308-8146(02)00583-6

Cen, -H., He, -Y., 2007. Theory and application of near infrared reflectance spectroscopy in determination of food quality. Trends in Food Science and Technology. 18(2), 72-83. https://doi. org/10.1016/j.tifs.2006.09.003

Chen, -H., Song, -Q., Tang, -G., Feng, -Q., Lin, -L., 2013. The Combined optimization of Savitzky-Golay smoothing and multiplicative scatter correction for FT-NIR PLS Models. International Scholarly Research Notices. 2, 1-9. https://doi.org/10.1155/2013/642190

Cope, -M., Delpy, D, -T., 1988. System for long-term measurement of cerebral blood and tissue oxygenation on newborn infants by near infra-red transillumination. Medical and Biological Engineering and Computing. 26(3), 289-294. https://doi.org/10.1007/BF02447083

Cozzolino, -D., Cynkar, W, -U., Shah, -N., Smith, -P., 2011. Multivariate data analysis applied to spectroscopy: Potential application to juice and fruit quality. Food Research International. 44(7), 1888-1896. https://doi.org/https:// doi.org/10.1016/j.foodres.2011.01.041

Esteban-Díez, -I., González-Sáiz, J, -M., Pizarro, -C., 2004. An evaluation of orthogonal signal correction methods for the characterisation of Arabica and Robusta coffee varieties by NIRS. Analytica Chimica Acta. 514(1), 57-67. https:/ / doi.org/10.1016/j.aca.2004.03.022

Flores, -K., Sanchez, M, -T., Perez-Marin, -D., Guerrero, J, -E., Garrido-Varo, -A., 2009. Feasibility in NIRS instruments for predicting internal quality in intact tomato. Journal of Food Engineering. 91(2), 311-318. https://doi. org/10.1016/j.jfoodeng.2008.09.013

Golic, -M., Walsh, -K., Lawson, -P., 2003. Short-wavelength near-infrared spectra of sucrose, glucose, and fructose with respect to sugar concentration and temperature. Applied Spectros- copy. 57(2), 139-145. https://doi. org/10.1366/000370203321535033

Gómez, A, -H., He, -Y., Pereira, A, -G., 2006. Non-destructive measurement of acidity, soluble solids and firmness of satsuma mandarin using Vis-NIR spectroscopy techniques. Journal of Food Engineering. 77(2), 313-319. https:// doi.org/10.1016/j.jfoodeng.2005.06.036

Hai-bin, -Q., Dan-lin, -O., Yi-yu, -C. 2005. Background correction in near-infrared spectra of plant extract by orthogonal signal correction. Journal of Zhejiang University. 6(8), 838-843. https:// doi.org/10.1631/jzus.2005.B0838

Ignat, -T., Schmilovitch, -Z., Fefoldi, -J., Steiner, -B., Alkalai-Tuvia, -S. 2012. Non-destructive measurement of ascorbic acid content in bell peppers by VIS-NIR and SWIR spectrometry. Postharvest Biology and Technology. 74, 91-99. https:/ / doi. org/10.1016/j.postharvbio.2012.06.010

Jankovska, -R., Sustova, -K., 2003. Analysis of cow milk by near-infrared spectroscopy. Czech Journal of Food Sciences. 21(4), 123-128. https://doi. org/10.17221/3488-CJFS

Kusumiyati., Hadiwijaya, -Y., Putri, I, E., 2018. Determination of water content of intact sapodilla using near infrared spectroscopy. IOP Conference Series: Earth and Environmental Science. 207, 1-7. https://doi.org/10.1088/17551315/207/1/012047

Kusumiyati., Mubarok, -S., Hamdani, J, -S., Farida., Sutari, -W., Hadiwijaya, -Y., Putri, I, -E., Mutiarawati, -T. 2018. Evaluation of sapodilla fruit quality using near-infrared spectroscopy. Journal of Food, Agriculture and Environment. 16(1), 49-53. https://doi. org/10.1234/4.2018.5481

Kusumiyati., Mubarok, S., Hamdani, J, S., Farida, Sutari, W., Hadiwijaya, Y., Putri, I, E., 2017. Detection of ridge gourd (luffa acutangula) fruit quality during storage using near-infrared spectrometer. Proceeding of ISAE International Seminar, Bandar Lampung, pp. 225-238.

Kusumiyati., Farida., Sutari, -W., Hamdani, J, -S., Mubarok, -S., 2018. Pengaruh waktu simpan terhadap nilai total padatan terlarut, kekerasan dan susut bobot buah mangga arumanis. Jurnal Kultivasi. 17(3), 766-771. https://doi. org/10.24198/kultivasi.v17i3.18698 
Lanza,-E., Li, B,-W., 1984. Application for near infrared spectroscopy for predicting the sugar content of fruit juices. Journal of Food Science. 49(4), 995-998. https:/ / doi.org/10.1111/j.1365-2621.1984. tb10378.x

Laref, -R., Ahmadou, -D., Losson, -E., Siadat, -M., 2017. Orthogonal signal correction to improve stability regression model in gas sensor systems. Journal of Sensors. 6, 1-8. https://doi. org/10.1155/2017/9851406

Liu, -H., Xiang, -B., Qu, -L., 2006. Structure analysis of ascorbic acid using Nearinfrared spectroscopy and generalized two-dimensional correlation spectroscopy. Journal of Molecular Structure. 794(1-3), 12-17. https://doi. org/10.1016/j.molstruc.2006.01.028

Lue, -Q., Tang, -M., Cai, -J., Lu, -H., 2010. Long-term prediction of Zhonghua kiwi fruit dry matter by near infrared spectroscopy. Scienceasia. 36(3), 210215. https://doi.org/10.2306/scienceasia1513-1874.2010.36.210

Moraes, F, -P., Costa, R, -C., de Morais, C, L, -M., de Medeiros, F, G, -M., Fernandes, T, R, -N., Hoskin, R, -T., de Lima, K, M, -G., 2019. Estimation of ascorbic acid in intact acerola (Malpighia emarginata DC) fruit by NIRS and chemometric analysis. Horticulturae. 5(1), 1-12. https:// doi.org/10.3390/horticulturae5010012

Mouazen, A, -M., Saeys, -W., Xing, -J., De Baerdemaeker,- J., Ramon, -H., 2005. Near infrared spectroscopy for agricultural materials: An instrument comparison. Journal of Near Infrared Spectroscopy. 13(2), 87-97. https://doi. org/10.1255\%2Fjnirs.461

Munawar, A, -A., Budiastra, I, -W., 2009. Pendugaan mutu dalam buah mangga menggunakan spektroskopi reflektan infra merah dekat. Jurnal Keteknikan Pertanian. 23(1), 59-64. https://journal.ipb.ac.id/index.php/jtep/article/ view $/ 7348 / 5701$

Munawar, A, -A., von Hörsten, -D., Wegener, J, -K., Pawelzik, E., Mörlein, -D., 2016. Rapid and non-destructive prediction of mango quality attributes using fourier transform near infrared spectroscopy and chemometrics. Engineering in Agriculture, Environment and Food. 9(3), 208-215. https://doi.org/10.1016/j. eaef.2015.12.004
Nicolai, B, -M., Beullens, -K., Bobelyn, -E., Peirs, -A., Saeys, -W., Theron, K, -I., Lammertyn, -J., 2007. Nondestructive measurement of fruit and vegetable quality by means of NIR spectroscopy: A review. Postharvest Biology and Technology. 46(2), 99-118. https://doi. org/10.1016/j.postharvbio.2007.06.024

Oliveira, G, -A., Bureau, -S., Renard, C, M, -C., Pereira-Netto, A, -B., Castilhos, F, -D., 2014. Comparison of NIRS approach for prediction of internal quality traits in three fruit species. Food Chemistry. 143, 223-230. https://doi. org/10.1016/j.foodchem.2013.07.12

Petcharaporn, -K., Kumchoo, -S., 2014. Calibration model of \%titratable acidity (citric acid) for intact tomato by transmittance SW-NIR spectroscopy. International Journal of Agricultural and Biosystems Engineering. 8(8), 825-829. https:/ / doi. org/10.5281/zenodo.2672696

Pissard, -A., Pierna, J, A, -F., Baeten, -V., Sinnaeve, -G., Lognay, -G., Mouteau, -A., Dupont, -P., Rondia, -A., Lateur, -M., 2012. Non-destructive measurement of vitamin C, total polyphenol and sugar content in apples using near-infrared spectroscopy. Journal of the Science of Food and Agriculture. 93(2), 238-244. https://doi.org/10.1002/jsfa.5779

Sari, H, -P., Purwanto, Y, -A., Budiastra, I, -W., 2016. Pendugaan kandungan kimia mangga gedong gincu menggunakan spektroskopi inframerah dekat. Agritech. 36(3), 294-301. https://doi. org/10.22146/agritech.16599

Schmilovitch, -Z., Mizrach, -A., Hoffman, -A., Eozi, -H., Fuchs, -Y., 2000. Determination physiological indices by near-infrared spectrometry. Postharvest Biology and Technology. 19(3), 245252. https://doi.org/10.1016/S09255214(00)00102-2

Shao, -Y., He, -Y., 2008. Nondestructive measurement of acidity of strawberry using Vis/NIR Spectroscopy. International Journal of Food Properties. 11(1), 102-111. https://doi. org/10.1080/10942910701257057

Suhandy, -D., 2010. Penentuan kandungan padatan terlarut buah jeruk BW secara tidak merusak menggunakan near infrared spectroscopy. Agritech. 30(1), 32-37. https://doi.org/10.22146/agritech.9689 
Jurnal Teknologi Pertanian Vol. 21 No. 3 [Desember 2020] 145-154

Prediksi Vitamin C, Total Asam Tertitrasi, dan Total Padatan Terlarut Pada Buah Mangga [Kusumiyati dkk]

William, P., Norris, K. 1990. Near Infrared Technology in the Agricultural and Food Industries. American Association of Cereal Chemiist, Inc

Yan-De, -L., Xing-Mao, -C., Xu-Dong, -S., Yi-Bin, -Y., 2007. Non-destructive measurement of pear internal quality indices by visible and near-infrared spectrometric techniques. New Zealand Journal of Agricultural Research. 50(5), 1051-1057. https://doi. org/10.1080/00288230709510385 